\title{
Effect of pasteurization and season on the sensorial and rheological traits of Mexican Chihuahua cheese
}

\author{
Diane L. VAN HeKKen ${ }^{1 *}$, Mary Anne DraKE ${ }^{2}$, Michael H. TUNICK ${ }^{1}$, \\ Victor M. GUERRERO ${ }^{3}$, F. Javier MOLINA-CORRAL ${ }^{3}$, Alfonso A. GARDEA ${ }^{3}$ \\ ${ }^{1}$ United States Department of Agriculture, Agricultural Research Service, Dairy Processing \& Products \\ Research Unit, 600 East Mermaid Lane, Wyndmoor, Pennsylvania 19038, USA \\ ${ }^{2}$ Department of Food Science, Southeast Dairy Research Center, North Carolina State University, \\ Raleigh, North Carolina 27695, USA \\ ${ }^{3}$ Centro de Investigación en Alimentación y Desarrollo, Cuauhtémoc, Chihuahua, 31570, Mexico
}

\begin{abstract}
The seasonal changes in the flavors and textures (sensorial and rheological traits) of young Mexican Chihuahua cheese made with either raw or pasteurized bovine milk (RM or PM, respectively) were determined to identify factors that contribute to the variability in the traditional flavors and textures of the cheese. Four selected brands of Chihuahua cheese from northern Mexico were obtained within days of manufacture during the winter, spring, and summer seasons and stored at $4{ }^{\circ} \mathrm{C}$ until evaluated; at day 10 for rheology and between days 14 to 18 for sensory. Descriptive analyses of flavors and textures were conducted with panelists trained to a universal or productspecific Spectrum $^{\mathrm{TM}}$ intensity scale, respectively. Microbial analyses were conducted prior to testing to ensure product safety. Rheological properties were measured using texture profile, small amplitude oscillatory shear, and torsion analyses. Results showed that the most prominent attributes in the young cheeses were: salty, sour, diacetyl, cooked, whey, bitter, and milkfat flavors with RM cheeses having more intense sour and bitter notes compared to the PM cheeses. Many cheese texture attributes were similar, but RM cheeses were perceived as softer than the PM cheeses. Rheological results supported that the RM cheeses were softer and their properties more variable than the PM cheeses. Seasonal differences were within expected brand-to-brand variation although RM cheeses had more variability than the PM cheeses. Only a few significant correlations were found among the rheological and the sensorial texture attributes which indicated that they evaluated cheese texture in different ways. As the demand for Hispanic-style cheeses increases, defining and understanding the sensorial and rheological attributes of traditionally made Mexican cheeses provides guidance to the cheese manufacturers as new ways are explored to manufacture the pasteurized version of the cheese.
\end{abstract}

cheese / Chihuahua cheese / rheology / sensory

摘要 - 热处理和季节对墨西哥 Chihuahua 干酪感官流变特性的影响。为了确定 影响传统手酪风味和质构的可变因素, 本文测定了由生鲜牛乳(RM酪) 和巴氏 杀菌乳 (PM 干酪) 加工的成熟初期墨西哥 Chihuahua 干酪的风味和质构(感官和 流变特性) 随季节性的变化。在墨西哥北部地区选择四个品牌的 Chihuahua 干酪,

* Corresponding author (通讯作者): diane.vanhekken@ars.usda.gov 
分别于冬季、春节和夏季生产的当天采样, $4{ }^{\circ} \mathrm{C}$ 㲸藏备用; 在第 10 天分析样品的流变性, 第 14-18 天进行感官评定。经过培训的感官评定人员分别采用通用和专用的 Spectrum ${ }^{\mathrm{TM}}$ 法对 干酪的风味和质构进行了描述性分析。为了确保产品的安全性, 在感官评定之前先测定了干 酪的微生物指标。以质构测定、小振幅震振荡剪切和扭转分析对年酪的流变特性进行了描 述。结果表明, 发酵初期干酪的典型风味是咸味、酸味、联乙䤈味、蒸煮味、乳清味、苦味 和乳脂肪味, RM 干酪比 PM 干酪具有更浓的酸味和苦味。许多干酪的质构特性非常相似, 但是 RM 干酪比 PM 干酪更软。流变学分析结果也证明了 RM 干酪较软, 而且一些性质更不 稳定。尽管 RM 干酪性质的变化幅度比 PM 干酪大, 但是在各品牌之间由于季节性变化引起 差异还是在可接受的范围内。在用不同的评价方法给出的结果中, 只有为数不多样品的流变 性和感官质构之间具有显著的相关性。随着对 Hispanic 型干酪需求量的增加, 确定和掌握传 统墨西哥干酪的感官和流变特性, 对巴氏杀菌法生产墨西哥干酪生产具有指导作用。

\title{
干酪 / Chihuahua干酪 / 流变性 / 感官
}

\begin{abstract}
Résumé - Effet de la pasteurisation et de la saison sur les caractéristiques sensorielles et rhéologiques du fromage mexicain Queso Chihuahua. Les changements saisonniers de flaveur et de texture du fromage mexicain Queso Chihuahua à l'état jeune, produit à partir de lait de vache cru (RM) ou pasteurisé (PM), ont été déterminés pour identifier les facteurs qui contribuent à la variabilité dans les flaveurs et textures traditionnelles du fromage. Des fromages Queso Chihuahua de quatre marques sélectionnées du nord du Mexique ont été obtenus dans les premiers jours de fabrication au cours de l'hiver, du printemps et de l'été, et stockés à $4{ }^{\circ} \mathrm{C}$ jusqu'à leur évaluation, au $10^{\mathrm{e}}$ jour pour la rhéologie et entre les $14^{\mathrm{e}}$ et $18^{\mathrm{e}}$ jours pour l'analyse sensorielle. Les analyses descriptives des flaveurs et textures ont été conduites avec un jury entraîné à une échelle d'intensité soit universelle, soit spécifique de produit Spectrum ${ }^{\mathrm{TM}}$. Des analyses microbiologiques ont été effectuées avant évaluation pour assurer la sécurité du produit. Les propriétés rhéologiques ont été mesurées à l'aide du profil de texture, du cisaillement oscillatoire de petite amplitude, et des analyses de torsion. Les résultats ont montré que les descripteurs le plus souvent attribués aux fromages jeunes étaient : salé, acide, diacétyle, cuit, lactosérum, amer et matière grasse, avec une note plus intense d'acide et d'amer pour les fromages RM comparée à celle des fromages PM. Beaucoup d'attributs de texture étaient similaires, mais les fromages RM étaient perçus comme plus mous que les fromages PM. Les résultats rhéologiques ont montré que les fromages RM étaient plus mous et leurs propriétés plus variables que les fromages PM. Les différences saisonnières étaient incluses dans la plage de variation marque à marque attendue, bien que les fromages RM avaient une variabilité plus grande que les fromages PM. Seulement quelques corrélations significatives étaient trouvées parmi les attributs de texture rhéologiques et sensoriels, ce qui indiquait qu'ils évaluaient la texture du fromage de façons différentes. Comme la demande de fromages de type hispanique augmente, la définition et la compréhension des attributs sensoriels et rhéologiques des fromages mexicains fabriqués de façon traditionnelle procurent des conseils aux fabricants de fromage alors que sont explorées de nouvelles façons de fabriquer le fromage pasteurisé.
\end{abstract}

\section{fromage / Queso Chihuahua / rhéologie / analyse sensorielle}

\section{INTRODUCTION}

In the state of Chihuahua, Mexico, the Mennonite communities developed and produce a semi-hard cheese (Queso Chihuahua) that typically is consumed fresh (usually within 2-4 weeks from manufacture) and is noted for its flavor and melting properties. Traditionally, Mexican Queso Chihuahua has been made from raw bovine milk, but as food safety is- sues increase for cheeses sold with minimal aging, more manufacturers are pasteurizing their cheesemilk. However, there are concerns that the use of pasteurized cheesemilk will alter the traditional sensory traits (flavor and texture) of this cheese. Although Queso Chihuahua is one of the major variety of cheese consumed in northern Mexico, only a few papers have been published on its chemical and microbial/pathogen properties $[4,14,15]$. 
Scientists from the Agricultural Research Service, Wyndmoor, Pennsylvania, USA, and the Centro de Investigación en Alimentiación y Desarrollo (CIAD), Cuauhtémoc, Chihuahua, Mexico, recently completed a study that characterized the quality traits of the young Chihuahua cheese made with either raw or pasteurized bovine milk (RM or PM, respectively). A number of properties of the RM and PM Chihuahua cheeses have been reported including differences in manufacture procedures and the chemical [18], microbiological $[1,18]$, and rheological properties [17, 20]. In collaboration with researchers at North Carolina State University, the sensorial properties have also been characterized [19]. The portion of the study presented here examines the impact of heat treatment (pasteurization) and seasonality of the cheesemilk on the flavors, textures, and rheology of fresh Chihuahua cheese, and the relationships among texture and rheology traits of the fresh cheese.

\section{MATERIALS AND METHODS}

\subsection{Cheese samples}

Multiple blocks of Chihuahua cheese made from either RM (2 brands; RM1, RM2) or PM (2 brands; PM1, PM2) were obtained within $3 \mathrm{~d}$ of manufacture from four selected commercial cheese plants in the Chihuahua region of Mexico. Brands were selected based on compositional and rheology results from an earlier study [20]. Because several of the RM cheeses had similar chemical and rheological values, an informal flavor ranking was conducted in which Chihuahua cheese makers $(n=30)$ identified the 2 RM brands that were closest to the 'ideal Queso Chihuahua flavor'. Manufacturing parameters for the 4 brands of cheese varied from 32 or $37{ }^{\circ} \mathrm{C}$ for warming the cheesemilk prior to renneting, 30 to $40 \mathrm{~min}$ for coagulation, and 38 or $40{ }^{\circ} \mathrm{C}$ cooking temperatures with 15 to
60 min cooking times. Curds were cheddared for 20-90 min, salted at levels of 2$4 \%$, and pressed at 120 to 550 PA for 6 to $20 \mathrm{~h}$ (17). Cheese samples were collected during the three distinct northern Mexico seasons (winter, December-January; midspring, May; and late summer, September) and shipped overnight (in ice chests with sufficient cold pack to keep cheese between $4-8{ }^{\circ} \mathrm{C}$ during transport) to the Dairy Processing and Products Research Unit, Wyndmoor, PA.

At least two blocks of each brand were then repacked and shipped overnight to North Carolina State University for texture evaluation. Three blocks from each manufacture were opened aseptically and portions were sent immediately for microbiological testing to ensure the safety of cheeses prior to any sensory testing. A certified laboratory conducted microbiological screenings for the presence of Listeria monocytogenes, Escherichia coli O157:H7, Staphylococcus aureus enterotoxin and Campylobacter spp. Cheeses were stored at $4{ }^{\circ} \mathrm{C}$ until sensory evaluations or rheological analyses were conducted.

\subsection{Sensory analyses}

Cheese flavor and texture evaluations were conducted as described by Van Hekken et al. [19]. Cheeses were between 14 and $18 \mathrm{~d}$ old when evaluated. All samples were removed from the interior of the cheese blocks $\left(2.5 \mathrm{~cm}^{3}\right.$ cubes for flavor and $1.27 \mathrm{~cm}^{3}$ cubes for texture), placed in capped $60 \mathrm{~mL}$ soufflé cups, and tempered $\left(22{ }^{\circ} \mathrm{C}\right.$ for flavor and $15^{\circ} \mathrm{C}$ for texture) prior to testing. For each shipment, panelists evaluated samples of each of the four brands (in duplicate for flavor and in triplicate for texture) in a randomized block design over a 2-day period. The experienced flavor descriptive analysis panel ( $n=8$; minimum of $40 \mathrm{~h}$ of training) was trained to use a universal 
Spectrum $^{\mathrm{TM}} 15$-point intensity scale [12] based on a Lexicon developed for Cheddar cheese [7] as modified for Chihuahua cheese [19]. Panelists received intensive training using references anchored at 2.0 and 5.0 intensities. The experienced texture descriptive analysis panel $(n=15$, minimum of $20 \mathrm{~h}$ of training) used a 15point product-specific intensity scale [6] as described and modified by Brown et al. [2] using the Spectrum ${ }^{\mathrm{TM}}$ method.

\subsection{Rheological analyses}

Rheological properties were obtained as described by Van Hekken et al. [20]. Three blocks of same brand of cheese were removed from refrigerated storage at $10-\mathrm{d}$ and warmed to room temperature $\left(22^{\circ} \mathrm{C}\right)$ prior to the preparation of samples. All tests were conducted at $22 \pm 1{ }^{\circ} \mathrm{C}$. Torsion analysis was conducted using a torsion gelometer rotating at 2.5 RPM (Gel Consultants, Inc., Raleigh, NC, USA). Four plugs (27.5-mm length, 15-mm diameter) from each cheese block were milled to the appropriate capstan shape (10-mm center diameter) and samples twisted until the sample fractured. Gelometer software collected shear stress and shear strain at point of fracture and calculated the shear rigidity (ratio of stress to strain) at the point of fracture. Texture profile analysis was conducted using a universal testing machine (Sintech, Model SM-25-155, Material Testing Products Systems Corp., Eden Prairie, MN, USA). Four cylindrical plugs (14.5-mm diameter and height) from each cheese block were compressed by $75 \%$ twice using a crosshead speed of $100 \mathrm{~mm} \cdot \mathrm{min}^{-1}$. Hardness, cohesiveness, and springiness were calculated by the instrument's software from the generated force-distance curves. Chewiness was calculated by multiplying the hardness, springiness, and cohesiveness values. Small amplitude oscillatory shear analysis was conducted using a Dynamic An- alyzer (model AR 2000, TA Instruments, New Castle, DE, USA). Three discs (25.4× 4-5 $\mathrm{mm}$ ) from each cheese block were prepared by gluing the cheeses to parallel plates. The linear viscoelastic range for each cheese was determined by a strain sweep. Frequency sweeps (0.1 to $100 \mathrm{rad} \cdot \mathrm{s}^{-1}$ ) then were conducted at $0.8 \%$ strain and the elastic and viscous moduli measured by the instrument's software were used to calculate the complex viscosity; values presented were obtained at $10 \mathrm{rad} \cdot \mathrm{s}^{-1}$.

\subsection{Statistics}

The experiment had a split plot design with the type of cheese (RM or PM) as the main effect. Sensory and rheology data were evaluated by analysis of variance using MIXED procedure (SAS Version 8.2; SAS Inc., Cary, NC, USA) to determine significance of main effects and interactions among cheese type, brand, and season. Differences were considered significant when $P<0.05$. Correlation coefficients were calculated between sensory texture and rheological properties.

\section{RESULTS AND DISCUSSION}

\subsection{Cheese}

Our earlier characterization studies described Chihuahua cheese from the Chihuahua region of Mexico as a pale yellow cheese with firmly packed curds. The composition of the 4 brands of cheeses used in this study were similar $(P>0.05)$ throughout the year; 39-41\% moisture, $24-26 \%$ protein, $31-34 \%$ fat, and $1.0-1.5 \%$ salt [17]. The RM cheeses contained more $(P<0.05)$ aerobic and anaerobic bacteria than the PM cheeses. All cheeses contained lactococci and lactobacilli whereas only the RM cheeses 

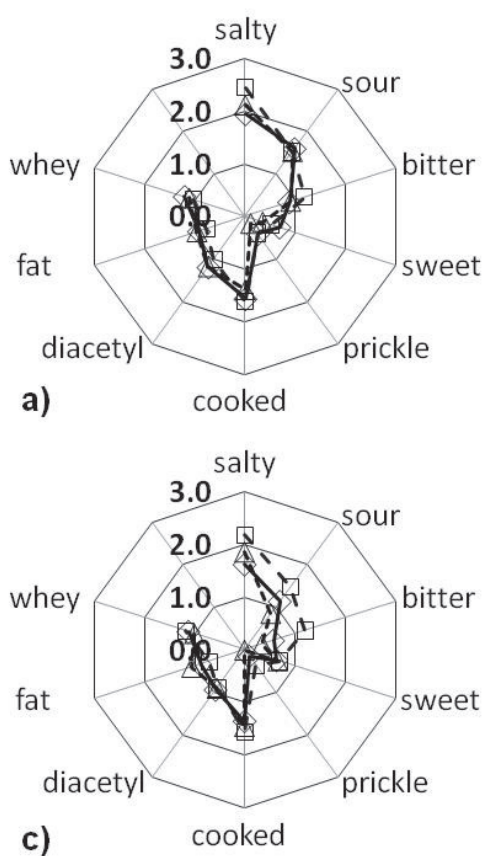
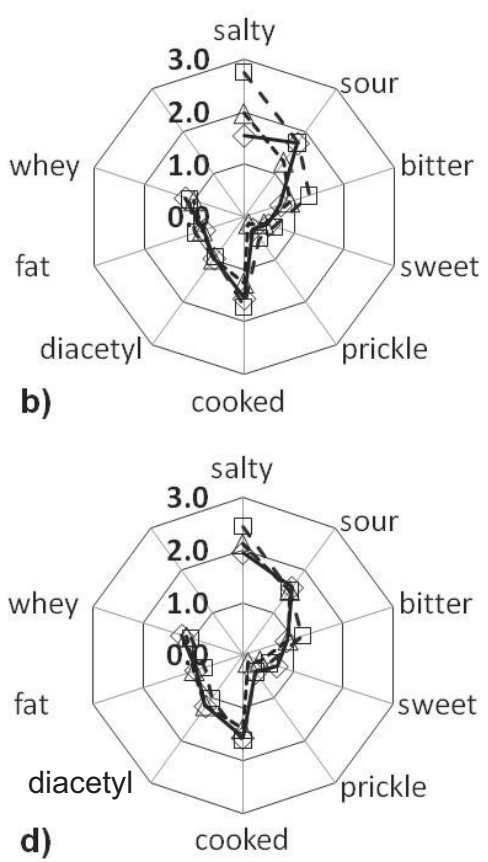

Figure 1. Variation in the sensory flavor profiles of Chihuahua cheese made with raw milk (brands a) RM1 and b) RM2) and pasteurized milk (brands c) PM1 and d) PM 2) during the winter ( $\diamond)$, spring $(\square)$, and late summer $(\Delta)$. Means based on duplicate evaluation per each sample of cheese.

contained additional coliforms and enterococci [1]. The RM cheeses had numerous pinhole sized gas openings throughout the matrix while the PM cheeses only had a few scattered gas holes.

\subsection{Sensory flavor}

Characterization of 16 different brands of Chihuahua cheese from Mexico established that this cheese has a mild flavor with the highest intensity scores (on a universal intensity scale) measured at 3.0 [19]. The most prominent attributes of the young cheeses were salty, sour, diacetyl, cooked, whey, bitter, and milkfat flavors with RM cheeses having more intense sour and bitter notes compared to the PM cheeses. There were slight seasonal variations noted among the 4 brands collected during the 3 different Mexican seasons (Fig. 1). Salt (ranged from 1.8 to 2.8 ), sour (ranged from 0.7 to 2.6 ), and bitter (ranged from 0.4 to 1.9 ) intensities were higher $(P<0.05)$ in RM cheeses than the PM cheeses. Cheeses made in the spring had the highest $(P<0.05)$ bitter and cooked scores while RM2 had the highest salt and sour scores. Diacetyl, whey, and milk fat aromas and flavors did not change significantly from season to season.

Chihuahua cheese has been described as "mild to tangy" in flavor [9]. Sour and bitter tastes noted in the cheeses could explain the tangy flavor. Chihuahua cheese is typically consumed as a young cheese (within 2-4 weeks after manufacture); therefore the cheeses were evaluated within $18 \mathrm{~d}$ after manufacture. The presence of young 
cheese flavors (cooked, whey, and diacetyl) were expected to predominate [7]. Although the intensity of some flavor notes, such as salt (1.8 to 2.8), reflected the chemical composition of the cheeses (1.0-1.5\% salt); others, such as milkfat-lactone flavor (0.7 to 1.3$)$, did not correspond to the $31-34 \%$ fat content of the cheese. Many factors impact flavor identification including panelists thresholds for different compounds, release of compounds from the cheese matrix, and masking from other tastes and flavors in the cheeses [5].

Seasonality of the milk is just one of many factors that can influence cheese flavor [11]. Not only can the gross composition of the milk change with the seasons but concentrations of enzymes and other minor components can be altered and feeddependent compounds can be transferred into the milk, such as grassy and onion flavor components [16]. Seasonality can also influence the microflora found in the RM cheeses which can alter proteolysis and lipolysis within the cheese matrix and thus influence flavor and texture $[3,13]$.

\subsection{Sensory texture}

The sensory texture attributes for fresh Chihuahua cheese from Mexico scored in the middle range (Fig. 2), as expected for a semi-hard fresh cheese [19]. The highest scores (9.1 to 9.5) were given to hand firmness, hand springiness, and first-bite firmness while chewdown degree of breakdown was at 7.3. The next cluster of scores (6.2-6.5) included hand rate of recovery, first-bite fracturability, chewdown cohesiveness, chewdown adhesiveness, and residual smoothness of mouth coating. Chewdown smoothness had the lowest score of 5.8. When compared to the reference cheeses described by Brown et al. [2], Chihuahua cheese was firm, but not hard, and had some springiness to its matrix. When compressed by hand, it re- covered fairly well but did not fracture or chewdown easily. When chewed, the mass was sticky in the mouth and slightly smooth. The RM cheeses were perceived as softer than the PM cheeses.

Season, brand, and season-brand interactions affected $(P<0.05)$ most of the sensory texture attributes (Fig. 2); only chewdown degree of breakdown and chewdown adhesiveness did not show seasonal changes. The most drastic changes in texture were the very low scores noted for the hand springiness and rate of recovery attributes of the RM cheeses made in late summer. The lower scores suggested weaker cheese matrices that were unable to recover their shape after hand manipulation compared to cheeses made at other times of the year. Cheeses made in the winter were softer (hand firmness or first-bite firmness $)(P<0.05)$ than cheeses made in the spring or summer. The late summer RM1 and PM1 cheeses broke down easier than cheeses made in other seasons as seen by higher $(P<0.05)$ first-bite fracturability and lower chewdown smoothness and residual smoothness of mouth coating values. The PM1 cheeses had the highest $(P<0.05)$ chewdown and residual smoothness properties and lowest firmness and fracture traits of all the brands. Outside of late summer cheeses having very low hand springiness and recovery, the other variations noted in the texture profiles of fresh Chihuahua cheese were within expected brand-to-brand variation of the cheeses.

\subsection{Rheology}

Characterization of the rheological properties of 16 brands of fresh Chihuahua cheese showed significant $(P<0.05)$ variation among the different brands and overlap among the RM and PM cheeses; although the PM cheeses had narrower ranges indicating more uniformity among 

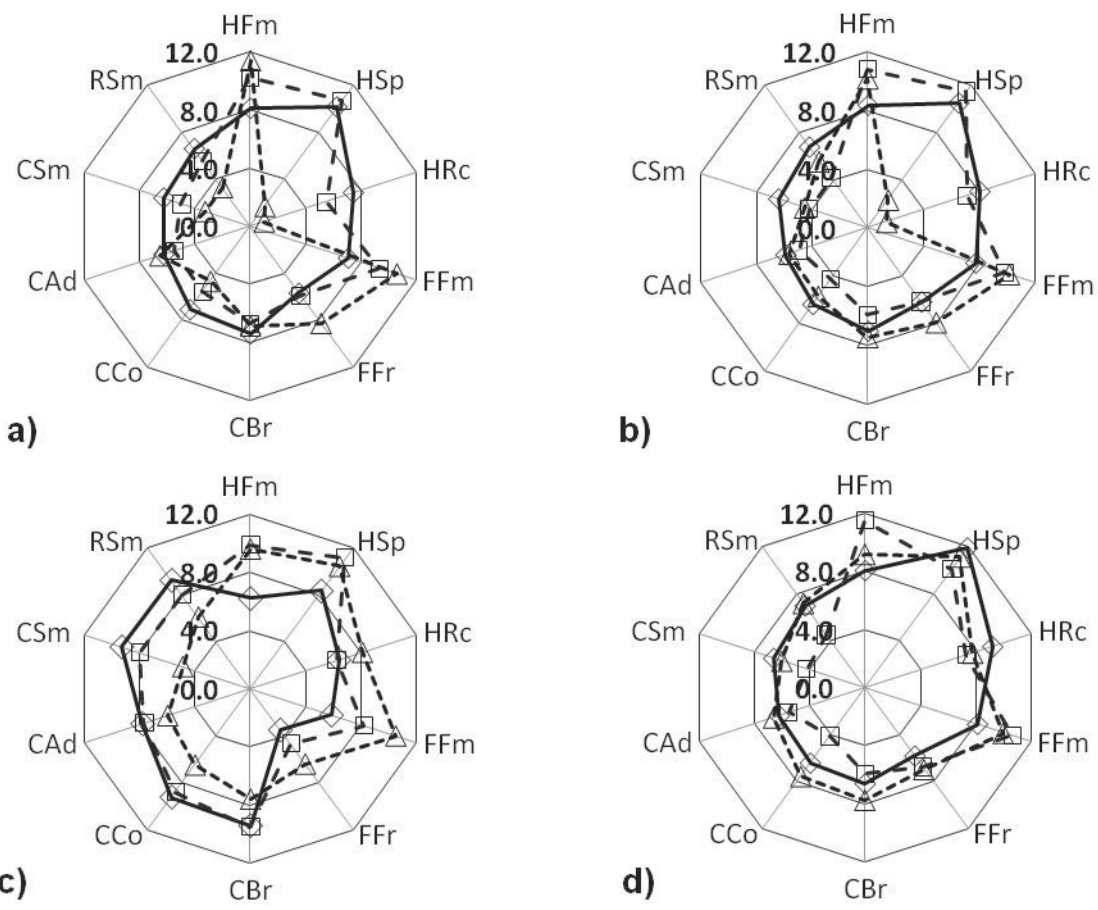

Figure 2. Variation in the sensory texture profiles of Chihuahua cheese made with raw milk (brands a) RM1 and b) RM2), and pasteurized milk (brands c) PM1 and d) PM2) during the winter ( $\diamond$ ), spring ( $\square$ ), and late summer $(\Delta)$. Means based on triplicates evaluation per each sample of cheese. Texture descriptors: hand firmness, HFm; hand springiness, HSp; hand rate of recovery, HRc; first bite firmness, FFm; first bite fracturability, FFr; chewdown degree of breakdown, CBr; chewdown cohesiveness, CCo; chewdown adhesiveness, CAd; chewdown smoothness, CSm; and residual smoothness of mouth coating, RSm.

the cheeses [20]. Based on texture profile analysis (TPA), which measures the cheese matrices response to double compression testing, the PM cheeses generally were harder, chewier, and more cohesive than the RM cheeses. Torsion analysis, which uses a fundamental approach to measure properties at the point of fracture, showed that the RM and PM cheeses fractured at similar stress, tolerated the same amount of twisting force, and had similar shear rigidity values at the point of failure. The small amplitude oscillatory shear analysis (SAOSA), which tests internal protein interactions using very small, non-destructive movements, demonstrated that the RM cheeses had higher values for their viscoelastic properties (elastic modulus, viscous modulus, and complex viscosity) than the PM cheeses.

The rheology data collected on 10day old Chihuahua cheese collected during the winter, spring, and summer showed that, while overall averages indicated that PM cheeses were harder, chewier, and more cohesive than the RM cheeses [18], there were noticeable variation among the brands and the tests. The TPA data (Fig. 3) showed that PM2 and both RM cheeses were harder when made in the summer 

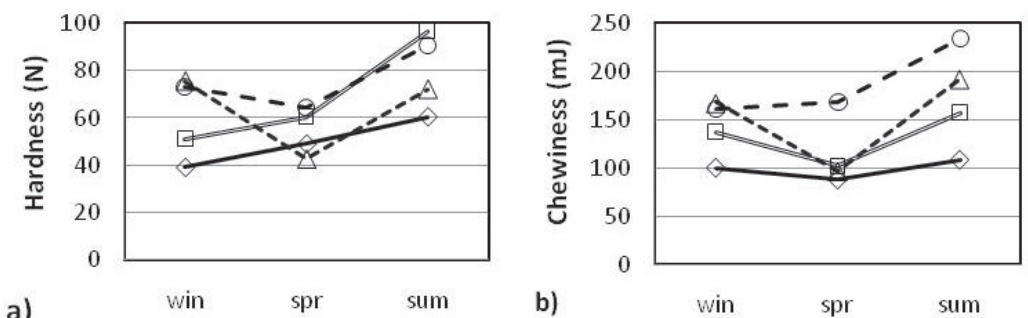

a)
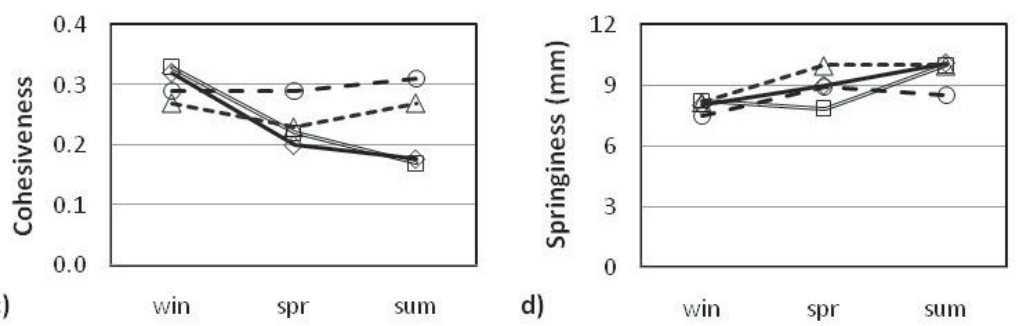

Figure 3. Changes in texture profile analysis properties (a) hardness, b) chewiness, c) cohesiveness, and d) springiness) across seasons (winter, win; spring, spr; and late summer, sum) for Chihuahua cheese made with raw milk (brands RM1 $(\diamond)$ and RM2 $(\square)$ ) or pasteurized milk (brands PM1 $(\Delta)$ and PM2 $(\bigcirc)$ ). Means based on triplicate replications/block of cheese with three blocks per each sample of cheese.

than at other times of the year. Chewiness values were highest $(P<0.05)$ for the RM2, PM1, and PM2 cheeses made in the summer while values for the RM2 and PM1 cheeses were lowest $(P<0.05)$ in the spring. The cohesiveness of the RM cheeses were highest $(P<0.05)$ in the winter and lowest $(P<0.05)$ in the summer. The cohesiveness values for the PM cheeses were consistent $(P>0.05)$ throughout the year. Cheeses made during the winter had the lowest TPA springiness values. Overall, torsion tests showed that cheeses made in the summer fractured at higher $(P<0.05)$ stresses and lower $(P<0.05)$ strains than cheeses made in the winter (Fig. 4). There were some brand variations. The spring RM1 cheese had the lowest shear stress value, while PM2 consistently had the highest shear strain values, and the summer RM2 cheese had the highest shear rigidity. The viscoelas- tic properties were consistent $(P>0.05)$ among the brands and throughout the year for Chihuahua cheese (Fig. 5). Some of the differences in rheological properties that were noted were contributed to brandto-brand variation although a few properties clearly had seasonal trends, such as cheeses made in the summer had stronger cheese matrices (highest hardness, chewiness, and shear stress) while cheeses made in the winter were not as flexible (low TPA springiness and shear strain values).

\subsection{Comparison of sensory texture and rheology characteristics}

The significant $(P<0.05)$ correlations between the sensory texture and rheological properties are listed in Table I. Torsion analysis provided the best response to the sensory terms. Both shear stress, the 

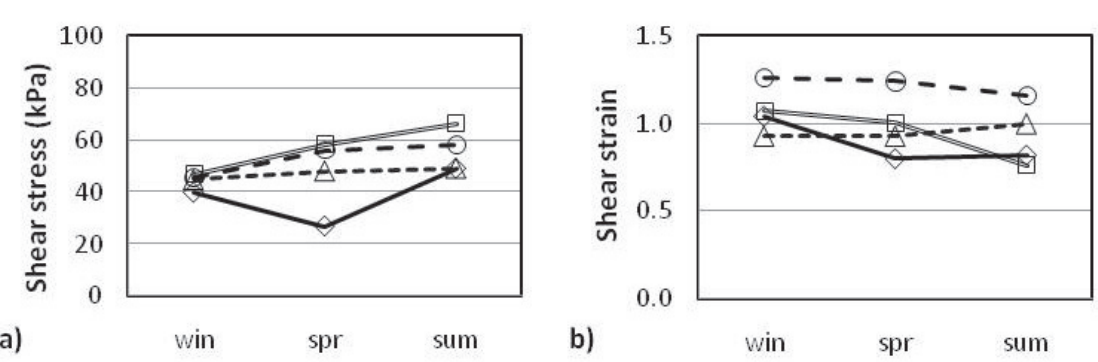

a)

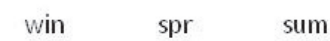

b)

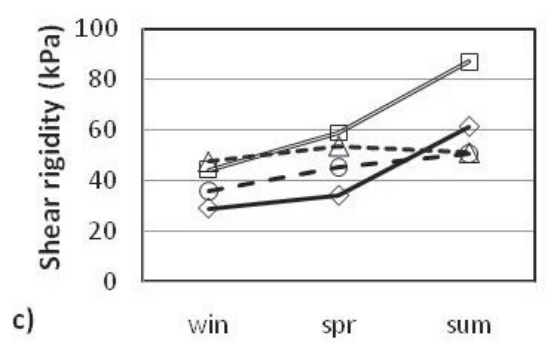

Figure 4. Changes in torsion analysis properties (a) shear stress at fracture, b) shear strain at fracture, and c) shear rigidity at fracture) across seasons (winter, win; spring, spr; and late summer, sum) for Chihuahua cheese made with raw milk (brands RM1 $(\diamond)$ and RM2 ( $\square$ )) or pasteurized milk (brands PM1 $(\Delta)$ and PM2 $(\bigcirc)$ ). Means based on four replications/block of cheese with three blocks per each sample of cheese.

Table I. Pearson correlation coefficients for sensory texture attributes and rheological properties $(n=6)$.

\begin{tabular}{lccccc}
\hline & Springiness & Cohesiveness & Shear stress & Shear strain & Shear rigidity \\
\hline Hand springiness & & & $-0.847^{*}$ & & $-0.924^{* *}$ \\
$\begin{array}{l}\text { Hand rate of recovery } \\
\text { First-bite firmness }\end{array}$ & $0.867^{*}$ & $0.823^{*}$ & $-0.837^{*}$ & $0.874^{*}$ & $-0.959^{* *}$ \\
$\begin{array}{l}\text { First-bite fracturability } \\
\text { Chewdown cohesiveness }\end{array}$ & & & & \\
$\begin{array}{l}\text { Residual smoothness } \\
\text { of mouth coating }\end{array}$ & & $0.825^{*}$ & & $0.852^{*}$ \\
\hline
\end{tabular}

$* P<0.05 ; * *<0.01$.

amount of force needed to fracture the cheese matrix, and shear rigidity, the ratio of shear stress/strain, have positive correlations to first-bite fracturability; which is not unexpected as both terms define ability to fracture. The two torsion terms also have negative correlations to hand springiness and hand rate of recovery, terms that refer to the ability for the matrix to flex and hold on to its form. Shear strain, which measures how much deformation the matrix will tolerate before fracturing, was positively correlated to hand rate of recovery and chewdown cohesiveness, both terms suggesting flexibility of the matrix to hold together when strained. Only two 

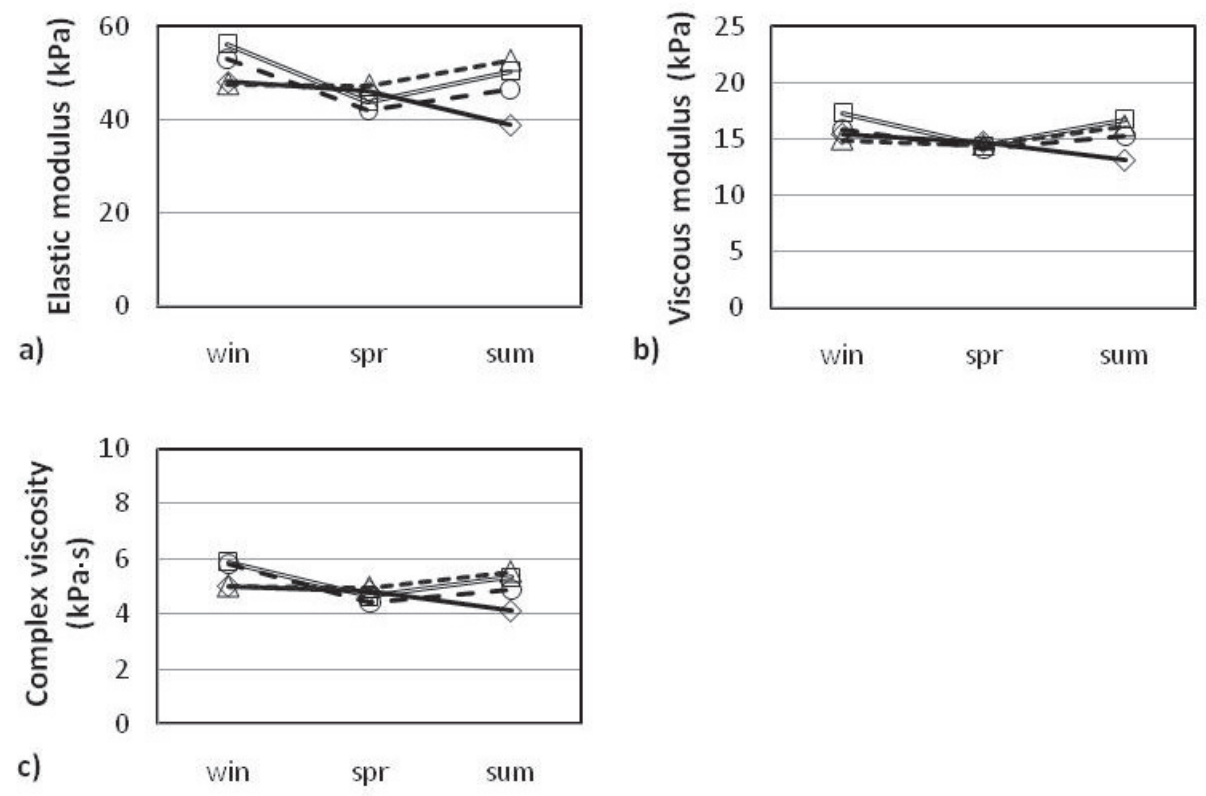

Figure 5. Changes in small amplitude ocillatory strain analysis properties (a) elastic modulus, G'; and b) viscous modulus, G') across seasons (winter, win; spring, spr; and late summer, sum) for Chihuahua cheese made with raw milk (brands RM1 $(\diamond)$ and RM2 ( $\square$ )) or pasteurized milk (brands PM1 $(\Delta)$ and PM2 $(\bigcirc)$ ). Means based on triplicate replications/block of cheese with three blocks per each sample of cheese.

of the TPA properties correlated to sensory traits. Springiness was positively related to first-bite firmness, which suggests the ability to hold a shape is indicative of the force needed in the first bite. Cohesiveness was related to hand rate of recovery which supports that the term describes the ability of the cheese matrix to hold together; the link between cohesiveness and residual smoothness of mouth coating is less clear. None of the viscoelastic terms correlated with the sensory traits. Only torsion shear strain, which reflects the amount of deformation that a cheese matrix can withstand before fracture, correlated with low hand springiness and hand rate of recovery. These were the two sensory attributes that were very low in the RM cheese made in late summer. Sensorial descriptors for cheese texture do not always correlate well to rheological properties [8]. Sensory and rheology tests are designed to measure the texture of cheese in different ways and conditions are not the same; for example, the rate and extent of deformation is not the same among panelists and is not the same as found in rheology tests. Hand and firstbite firmness usually correlates well with rheology terms for hardness/firmness, but chewdown terms are specifically difficult to compare because they are influenced by the mixing and solubilization of the cheese with saliva, food manipulation within the mouth, and changing temperature of the food as it is chewed; conditions typically not found in rheological tests. In addition, 
significant correlations can be coincidental and results must be examined for logical mechanisms.

The response of the cheese protein matrix to different stresses and strains can be influenced by a number of different factors. The composition of the final cheeses were very similar $(P>0.05)$ and probably was not a major factor in the differences noted in the rheology. Cheeses were manufactured using different parameters including: coagulated milk was cut into cubes ranging in size from 6 to $25 \mathrm{~mm}^{3}$ in size, cooked at 37 to $40{ }^{\circ} \mathrm{C}$ for 15 to $60 \mathrm{~min}$, cheddared for 20 to $90 \mathrm{~min}$, and pressed overnight at 120 to $550 \mathrm{~Pa}$ [17]. Each of these parameters can influence the formation and final form of the cheese matrix and would affect the rheology of the cheese. In an earlier evaluation of 16 brands of Chihuahua cheese made with either RM or PM, Tunick et al. [17] reported that differences in manufacturing protocols had relatively little impact on the final product, only the reduction of microflora by the pasteurization of the cheese milk produced noticeable differences in cheese traits. Because of these findings, the impact of manufacturing differences are included in the brand-to-brand variation noted in the present study.

The presence of the indigenous microflora in the cheeses will impact the status of the cheese matrix, even after only $10 \mathrm{~d}$ of aging. In a project on Pecorino del Poro, a RM cheese from Italy, researchers reported higher diversity of mesophilic lactobacilli and cocci in cheeses made in the spring compared to the thermophilic lactobacilli and cocci in the cheeses made in the summer [3]. Enzymes released by the microflora, indigenous to the milk (such as plasmin) and added to the cheesemilk (such as chymosin) influence the degree of proteolysis and lipolysis within the cheese matrix and thus influence flavor and texture $[3,13]$. Significant proteolysis [10] and solubilization of the calcium phosphate [11] within the cheese matrix over the first 2-weeks after manufacture contributes to the initial softening of the cheese matrix.

The protein matrix is the foundation for the quality traits of cheese as it controls the distribution and release of flavor compounds, imparts mouth feel, determines how the cheese will slice, shred, or crumble, and controls the degree to which a cheese will melt. Both sensory texture and rheological tests provide information about the properties of the cheese matrix from different perspectives and furthers our understanding of the quality traits of the cheese. Sensory and rheological findings showed differences between the RM and PM cheese while the variations seen from season to season were within brand-to-brand variation noted in Mexican Chihuahua cheese. As the demand for Hispanic-style cheeses increases, defining and understanding the sensorial and rheological attributes of traditionally made Mexican cheeses provides guidance to cheese makers as new ways are explored to improve the production and shelf life of the cheese.

Acknowledgements: The authors thank J. Phillips for statistical guidance, J. Shieh for SAOSA rheological data, and the sensory panelists involved in this study. Partial support for this project was funded by the USDA, Foreign Agricultural Service, Scientific Cooperative Research Program, and Dairy Management Inc. (Rosemont, IL, USA).

\section{REFERENCES}

[1] Bricker A.L., Van Hekken D.L., Guerrero V.M., Gardea A.A., Microflora isolated from Mexican Mennonite-style cheeses, Food Prot. Trends 25 (2005) 637-640.

[2] Brown J.A., Foegeding E.A., Daubert C.R., Drake M.A., Gumpertz M., Relationships among rheological and sensory properties of young cheeses, J. Dairy Sci. 86 (2003) 30543067 . 
[3] Caridi A., Micari P., Caparra P., Cufari A., Sarullo V., Ripening and seasonal changes in microbial groups and in physio-chemical properties of the ewes' cheese Pecorino del Poro, Int. Dairy J. 13 (2003) 191-200.

[4] Diaz-Cinco M.E., Fraijo O., Grajeda P., Lozano-Taylor J., Gonzalez de Mejia E., Microbial and chemical analysis of Chihuahua cheese and relationship to histamine and tyramine, J. Food Sci. 57 (1992) 355-356, 365.

[5] Drake M.A., Defining dairy flavor, J. Dairy Sci. 87 (2004) 777-784.

[6] Drake M.A., Gerard P.D., Truong V.D., Daubert C.R., Relationship between instrumental and sensory measurements of cheese texture, J. Texture Studies 30 (1999) 451476.

[7] Drake M.A., McIngvale S.C., Gerard P.D., Cadwallader K.R., Civille G.V., Development of a descriptive language for cheddar cheese, J. Food Sci. 66 (2001) 1422-1427.

[8] Foegeding E.A., Drake M.A., Sensory and mechanical properties of cheese texture, J. Dairy Sci. 90 (2007) 1611-1624.

[9] Kosikowski F.V., Mistry V.V., Cheese and Fermented Milk Foods, Vol. 2, 3rd edition, Kosikowski F.V. (Ed.), LLC, Westport, CT, USA, 1997.

[10] Lawrence R.C., Creamer L.K., Gilles J., Texture development during ripening, J. Dairy Sci. 70 (1987) 1748-1760.

[11] Lucey J.A., Johnson M.E., Horne D.S., Perspective on the basis of the rheology and texture properties of cheese, J. Dairy Sci. 86 (2003) 2725-2743.

[12] Meilgaard M.M., Civille G.V., Carr B.T., Sensory Evaluation Techniques, 3rd edition, CRC Press, Boca Raton, FL, USA, 1999.
[13] Mendia C., Ibanez F.C., Torres P., Barcina Y., Influence of the season on proteolysis and sensory characteristics of Idiazbal cheese, J. Dairy Sci. 83 (2000) 1899-1904.

[14] Saltijeral J.A., Alvarez V.B., Farcia B., Presence of Listeria in Mexican cheeses, J. Food Safety 19 (1999) 2141-247.

[15] Solano-Lopez C., Hernandez-Sanchez H., Behaviour of Listeria monocytogenes during the manufacture and ripening of Manchego and Chihuahua Mexican cheeses, Int. J. Food Microbiol. 62 (2000) 149-153.

[16] Tunick M.H., Origins of cheese flavor, in: Cadwallader K.R., Drake M.A., McGorrin R.J. (Eds.), Flavor of Dairy Products, ACS Symposium Series 971, Amer. Chem. Soc., Washington DC, USA, 2007, pp. 155-173.

[17] Tunick M.H., Van Hekken D.L., Call J., Molina-Corral F.J., Gardea A.A., Queso Chihuahua: Effects of seasonality of cheesemilk on rheology, Int. J. Dairy Technol. 60 (2007) 13-21.

[18] Tunick M.H., Van Hekken D.L., MolinaCorral F.J., Tomasula P.M., Call J., Luchansky J., Gardea A.A., Queso Chihuahua: manufacturing procedures, composition, protein profiles, and microbiology, Int. J. Dairy Technol. 61 (2008) 62-69.

[19] Van Hekken D.L., Drake M.A., MolinaCorral F.J., Guerrero Prieto V.M., Gardea A.A., Mexican Chihuahua cheese: Sensory profiles of young cheese, J. Dairy Sci. 89 (2006) 3729-3738.

[20] Van Hekken D.L., Tunick M.H., Tomasula P.M., Molina-Corral F.J., Gardea A.A., Mexican Queso Chihuahua: Rheology of fresh cheese, Int. J. Dairy Technol. 60 (2007) 5-12. 